\title{
A szérum lipidszintet csökkentő szerek hazai felhasználásának változása 2007-2015 közötti periódusban az OEP adatbázisa alapján
}

\author{
Barna István, Gyurcsányi András
}

\author{
SE, I.sz. Belklinika, Budapest
}

Levelezési cím: Dr. Barna István habil, 1083 Budapest, Korányi Sándor u. 2/a, E-mail: barpis@gmail.com

A vérnyomás és a koleszterinérték célértéken tartása meghatározó jelentőségü, hiszen ismert, hogy ezzel a korai kardiovaszkuláris halálozás több mint 75\%-a elkerülhetővé válhatna. Vizsgálatunk során az Országos Egészségpénztár (OEP) adatbázis alapján a szérum lipidszintet csökkentő szerek felhasználását elemeztük 2007 és 2015 közötti periódusban. A forgalom elemzése során megfigyelhettünk a 2010-2011 évben havi 800 ezer feletti dobozszámot, ami némi csökkenés után 700-750 ezer doboz kiváltásánál megállt. Az egyes lipidcsökkentők forgalma közt igen jelentős különbség figyelhető meg. A kiváltott gyógyszerek 87\%-a statin. 2007-ben a simvastatin volt a legnagyobb mértékben rendelt molekula. 2015-re az atorvastatin (40\%), és a rosuvastatin (36\%) felhasználás kiemelkedő, a simvastatinnak folyamatos csökkenés mellett, még több mint $9 \%$-os a részesedése. A vérnyomáscsökkentő(k) mellett fix kombinációban alkalmazott statinkezelés aránya ugyan még kicsi, de jóllehet a jobb beteg-együttmüködés reményében egyre nagyobb teret hódíthatnak az ilyen jellegü készítmények. Az OEP-adatok értelmezése során látható, hogy előbb jönnek a szakmai irányelvek, az evidenciával bíró közlemények, majd a szakvélemények, és ez lassan tükröződik a kialakult orvosi gyakorlat adataiban is.

Kulcsszavak: lipidszint-csökkentők, statinok, irányelv, OEP statisztika 2007-2015 között

Change in use of serum lipid lowering agents between 2007-2015 based on NHI data

Keeping the level of cholesterol and blood pressure at the target level is of decisive importance, since it is well known, that thanks to this, $75 \%$ of early cardiovascular death could be avoidable. Based on the NHI database we analysed the use of serum lipid level lowering agents between 2007 and 2015. Analysing the data in 2010 and 2011 we could observe more than 800 thousand boxes turnover monthly, which after slightly decrease stopped at $700-750$ thousand boxes. Among the turnovers of the different lipid level lowering agents significant difference can be observed. $87 \%$ of the booked drugs are statins. In 2007 simvastatin was the most frequently used molecule. By 2015 the use of atorvastatin (40\%) and rosuvastatin (36\%) was significant. The share of simvastatin is still $9 \%$ after continuous decrease. The rate of statin treatment used in fix combination is still low, although to reach better patient adherence there are even more combinations. Interpretation of $\mathrm{NHI}$ data it can be observed that first come professional guidelines, the evidence based publications than the expertise and these are slowly reflected in the hungarian medical practice as well.

Keywords: lipid level lowering agents, guidelines, NHI statistic between 2007 and 2015 


\section{Bevezető}

A szív- és érrendszeri halálozás elsődleges kockázati tényezője a túlsúlyosság, a zsíranyagcsere-zavar, az emelkedett vérnyomásérték, együttesen a metabolikus szindróma. Magyarországon 3-3,5 millió hipertóniás egyén él, a felnőtt magyar nők és férfiak több mint $40 \%$ a túlsúlyos (BMI=25-29,9 kg/m²), 20\%-a elhízott (BMI $>30 \mathrm{~kg} / \mathrm{m}^{2}$ ). Az extrém elhízásban szenvedök (BMI> 40 $\mathrm{kg} / \mathrm{m}^{2}$ ) száma mintegy 200 000-re tehető (esélyük a hirtelen szívhalálra 40 -szeres). A vérnyomás- és a koleszterinérték célértéken tartása meghatározó jelentőségü, hiszen ismert, hogy ezzel a korai kardiovaszkuláris halálozás több mint $75 \%$-a elkerülhetővé válhatna. A hipertónia okozta kardio- és cerebrovaszkuláris szövődmények az eddig lezárult valamennyi vizsgálat alapján bizonyítottan szoros összefüggésben állnak a hipertónia mértékével. A szekunder és primer hypercholesterinaemiák becsült prevalenciája Magyarországon mintegy 1,8 millió fö (1). Ennek jelentős részét a szekunder hyperlipoproteinaemiák adják, amelyek leggyakoribb oka az elhízás, metabolikus szindróma, 1-es és 2-es típusú diabetes mellitus, alkoholfogyasztás, hypothyreosis és a lipidanyagcserét kedvezőtlenül befolyásoló gyógyszerek szedése.

\section{A koleszterinszint csökkentése}

\section{Statinok}

A vér koleszterinszintje nem annyira a táplálkozástól, hanem inkább a szervezet örökölt, vagy kialakult endogén koleszterinszintézisétől függ. A diétától csak 5-10\%-os koleszterinszint-csökkenés várható, ezért gyógyszeres kezelést kell indítanunk familiáris esetekben és az igen nagy kockázatú betegségekben (pl. akut koronária szindróma). A legújabb európai dyslipidaemia guideline (2016 ESC/EAS Guidelines for the Management of Dyslipidaemias) is első választásként a statinokat ajánlja hypercholesterinaemia és emelkedett triglicerid-értékek esetén. A HMG-CoA-reduktáz-gátló statinok az LDL-koleszterinszintet 40-50\%-kal, az összkoleszterin-szintet pedig 25-30\%-kal csökkenthetik. A statinok, a hidroximetil-glutaril-koenzim-A-reduktáz (HMG-CoA) gátlók, a koleszterinszintézis egyik meghatározó lépését, a hidroximetil-glutaril-CoA mevalonáttá alakulását gátolják, ennek következtében az LDLreceptor aktivitását növelik, ami növeli a szérumból az LDL-részecskék eltávolítását.

Az elmúlt évek nagy epidemiológiai vizsgálatai közül első alkalommal 1994-ben a Scandinavian Simvastatin Survival Study (4S) keretében igazolták a kardiovaszkuláris kockázat csökkenését a simvastatinnal kezeltek körében. A Heart Protection Study-ban pedig arra hívták fel a figyelmet, hogy normális koleszterinérték esetén a fokozott kockázatú betegek kardiovaszkuláris rizikója csökkenthető (2). A simvastatinnal kapcsolatos nagy nemzetközi vizsgálatok eredményei a lipidológia meghatározó tényezőjévé tették a vegyületet (3). Az elmúlt 10 év során azonban hazánkban a simvastatin alkalmazása jelentős mértékben csökkent a korszerübb, hatékonyabb és jobban tolerálható statinok (atorvastatin, rosuvastatin) megjelenésével egyidejüleg. Akut koronária szindróma esetén a koleszterinszinttöl függetlenül $40 \mathrm{mg}$ rosuvastatin vagy $80 \mathrm{mg}$ atorvastatin javaslata már a 2011-ben megfogalmazott ajánlásban is olvasható volt. A néhány hetes kezelés után, a koleszterinszint csökkentése mellett a plakkok stabilizálódtak. A célértékre történő kezelés során az LDL-koleszterin célérték 1,8 $\mathrm{mmol} / /$, az összkoleszterin-célérték 3,5 $\mathrm{mmol} / \mathrm{l}$ (4). Az Amerikai Szív Társaság (American Heart Association) 2015-ben megfogalmazott ajánlásában minden 75 év alatti emelkedett LDL-koleszterin $(\geq 4,94$ $\mathrm{mmol} / \mathrm{l})$ értékủ, vagy nagy kockázatú betegek $(\geq 7,5 \%)$ körében atorvastatin $40-80 \mathrm{mg} /$ nap vagy rosuvastatin 20-40 mg/nap adását javasolja, hogy az LDL-koleszterin értéke $(\geq 50 \%)$ csökkenjen. 75 éves kor felett, vagy diabetes mellitus jelenléte esetén kisebb hatáserősségü statin (simvastatin 20-40 mg, atorvastatin 10-20 $\mathrm{mg}$, rosuvastatin 5-10 mg adását javasolja az LDL-koleszterin 30-50\%-os csökkentésére (5).

A statinterápia indításakor a megfelelő dózist a beteg CV rizikóállapota és a kiindulási koleszterinérték, valamint az elérendő célérték figyelembe vételével célszerủ meghatározni. A megfelelően megválasztott hatékony statinterápiát az átlagdózissal javasolt kezdeni és a maximális vagy a maximálisan tolerálható dózisig feltitrálni. A koleszterinszint-csökkentő hatás csak egy a statinokat jellemző számos egyéb hatás között. A pleiotrop hatás független a lipidcsökkentő hatástól és komplex módon érvényesül. Az endothelfunkció javítását, gyulladáscsökkentő hatást, thrombus képződés gátlását, plakk-stabilizálást elősegítő hatást és az oxidatív stressz csökkentését soroljuk ide (6). Ha a statinok hatását csak igen röviden akarjuk összegezni, akkor a koleszterinszint csökkentése mellett mindenekelőtt az endothel-diszfunkciót kedvezően befolyásoló hatását kell említeni. Mind a nitrogén-monoxidra, simaizomsejt-proliferációra, mind az endothelin-1-re kifejti hatását (7). Gyulladáscsökkentő hatását a leukocita-adhézióra hatva fejti ki. Megemlíthető antioxidáns hatása, mely az LDL-oxidáció, makrofág kötődés, habos sejtképződés csökkentésén keresztül érvényesül. A mátrix metalloproteináz (MMP-9) szekréció, simaizomsejt-proliferáció csökkentése mellett az angiogenezisre a VEGF-szint csökkentésén keresztül hat. Számos nemzetközi vizsgálat igazolta azt a tényt, hogy statinkezelés során a lipidszint csökkentésével párhuzamosan csökken a kardiovaszkuláris morbiditás és mortalitás. Ha a nemzetközi vizsgálatok eredményeit értékeljük, joggal fogalmazható meg, hogy a kisebb koleszterinértékek esetén a CV-kockázat is csökken. Bármelyik statint is alkalmazták, az átlagos 20-40\%-os csökkenés alapján minden endo- 
thelfunkció-károsodással járó kórkép esetén a statinok bázis szernek tekinthetők (8).

A statinok csökkentik a carotis ateroszklerózis mértékét, antiinflammációs és endothel-diszfunkciót csökkentő, trombocitaaggregáció-gátló hatásúak, továbbá feltehetőleg neuroprotektív effektussal is rendelkeznek (9). Az endothel-diszfunkciójával jellemzett ateroszklerózis komplex folyamat. Amennyiben közepes dózisú statinnal, $40 \mathrm{mg}$ atorvastatinnal, vagy $20 \mathrm{mg}$ rosuvastatinnal nem érjük el a célértéket, akkor inkább kombináció javasolható a koleszterin-felszívódást gátló ezetimibbel. A statinok alkalmazása mellett az esetek 5-10\%-ában fordul elő mellékhatás (myopathia, májenzim-emelkedés). Az izomfájdalom $Q_{10}$ adásával részben mérsékelhető (10).

A statinok számos előnye mellett azonban a JUPITER-vizsgálat rámutatott egy hátrányra is. A vizsgálat során a napi $20 \mathrm{mg}$ dózisú rosuvastatinnal kezelt betegek esetében az újonnan kialakult diabetes mellitus száma 25\%-kal nőtt. Egy 2011-ben publikált, átfogó randomizált, kontrollált vizsgálatban az az eredmény született, hogy a statinok 9\%-kal növelik a diabetes mellitus kialakulását, függően a kezelés időtartamától és a statin fajtájától. A vizsgálatok és metaanalízisek eredményei szerint a diabetes mellitus incidenciájának növekedése csoporthatás, amely kisfokú és dózisdependens. Az is biztosan kijelenthető, hogy a statinok kardiovaszkuláris rizikót csökkentő hatása fontosabb és előnyösebb, mint az esetleges diabetes mellitus miatt fellépő többletkockázat. A statinok az antiinflammatorikus hatásuk révén csökkentik a proinflammatorikus citokinek kedvezőtlen hatását, csökkentik az inzulinrezisztenciát, így jó tulajdonságaik többszörösen fölülmúlják az esetleges diabetogén hatásukat (11).

Hatás és mellékhatás tekintetében különbségek vannak a készítmények között a vízben-zsírban oldhatóságuk és egyéb tulajdonságaik szerint. Az egyik mellékhatás a statin-myopathia, amely az enyhe izompanaszoktól a (nagyon ritka) myoglobinuriáig terjed. A fizikai aktivitás heti néhány órában csökkenti a myopathia esélyét, számtalan egészségvédő hatással rendelkezik, ezért sem szabad, hogy a statint szedők csökkentsék a testmozgásukat. A statin elsősorban a gyors, glikolitikus II típusú rostokat károsítja, amelyek aránya és nagysága korosodással jelentősen csökken. A fizikai aktivitást kellene előbb elkezdeni a dyslipidaemiásoknak, és hetekkel-hónapokkal később a statin szedését. A fizikai aktivitást jobban be kellene építeni a kezelések menetébe az egyéb megelőző-gyógyító beavatkozások során is (12). $A Q_{10}$, a farnesyl, a dolichol adása ígéretes, de egyelőre nem bizonyított hatású a myopathia megelőzésében.

A célérték eléréséhez és a mellékhatások csökkentéséhez statin+ezetimib, statin+fenofibrat, statin+niacin kombinációkkal végeztek vizsgálatokat. Az LDL-koleszterin-csökkentéssel kapcsolatos vizsgálatok eredményei a klinikai végpontokat illetően további kérdéseket vetettek fel, megkérdőjelezték a kombinációs kezelés előnyét a statin monoterápiához képest (13).

\section{Biológiai szerek}

Inkább csak újdonsága miatt említjük meg a PCSK9et (szubtilizim/kexin proprotein-kenvertáz enzim 9-es típusát), hiszen széles körben egyelőre nem került be a mindennapi terápiába. A PCSK9-gátlók szignifikáns LDL-, összkoleszterin, Lp(a) csökkentő hatást fejtenek ki azáltal, hogy gátolják az LDL-receptor intracelláris lebontását és elősegítik annak sejtfelszínre történő viszszajutását. A II. és III. fázisú vizsgálatok homo- és heterozigóta familiáris hypercholesterinaemiában, valamint a magas rizikójú hypercholesterinaemiás betegekben rövidtávon és hosszútávon alkalmazva igazolták, hogy hatékony szerek mind monoterápiában, mind statinnal történő kombinációban $(14,15)$. Az Európai Bizottság az evolocumab PCSK9-gátló forgalomba hozatalát engedélyezte. A monoklonális antitest szelektíven kötődik az enzimhez és ezzel az LDL-receptor-denzitás növekedését okozza, amelynek révén a májsejtek több LDL-koleszterint képesek a keringésből kivonni, ezzel csökkentik az LDL-koleszterin-koncentrációt. Az ajánlásban önállóan, vagy statinnal kombináltan részben statin-intolerancia, hatástalanság esetén, illetve familiáris hypercholesterinaemia esetén adható. A subcutan alkalmazandó készítmény reményt jelent azon esetekben, akiknél a terápiás célértéket nem sikerült statinnal elérni. A statinnal történő együttes alkalmazás során a statin monoterápiához képest mintegy 50\%-os LDL-csökkenést képesek kiváltani, ezáltal az emelkedett kiindulási LDL-szinttel rendelkező, igen nagy rizikójú betegek nagy része eléri az 1,8 mmol/l-es kívánatos LDL-célértéket. Jelentős, mintegy 30\%-os Lp(a) csökkentő hatása nagy előrelépést jelenthet a magas Lp(a)-szinttel rendelkező betegek kezelésében.

Továbbra is kérdés az, hogy a védőhatású HDL-C emelése milyen mértékben járul hozzá a kardiovaszkuláris rizikó csökkentéséhez. A torcetrapib-, dalcetrapib-vizsgálatok eredményei nem bizonyították a kedvező hatást. Az újabb készítményekkel folyamatban lévő vizsgálatok anacetrapib (REVEAL), evacetrapib (ACCELERATE) eredményei segíthetnek a CETP-gátlók kardiovaszkuláris prevencióban történő alkalmazásának jobb megítélésében.

\section{Szérum lipidszintet csökkentő szerek felhasználása az OEP adatbázisa alapján} Módszertan

Az OEP minden hónapban közzéteszi a gyártói befizetési kötelezettségeket, amelyeket a patikák által elszámolt havi receptforgalomból számolnak ki. Az összehasonlíthatóság miatt minden év december hónap adatait elemeztük, ezek érdemben nem különböznek a többi hónap forgalmától. Az elemzés a kardiovaszkuláris 
rendszerre ható készítmények ATC szerinti besorolása alapján készült, mert az OEP is ezt használja a támogatásba befogadott gyógyszerek esetében (C10 csoport, szérum lipidszintet csökkentő szerek). Az adatok értékelését az elszámolt dobozforgalomból számoltuk. Társadalombiztosítással rendelkezők számára az OEP az orvosok által rendelt receptek esetében támogatást nyújthat (meghatározott indikációkban, meghatározott \%-os mértékben), ezzel csökkentve a betegek által fizetendő térítési díjakat. Emellett a betegek betegségükből adódóan vagy anyagi körülményeik miatt jogosultak lehetnek közgyógyellátás igazolványra, amellyel az OEP a gyógyszer teljes árát támogatja egy meghatározott keretösszegig. A közgyógyellátásban rendelhető gyógyszerek köre az OEP által támogatott készítmények közül kerül ki. Ezért is fontos értékelni, hogy az OEP által befogadott és támogatott készítmények felhasználása miként változik.

\section{Eredmények}

A 2007-2015 között, három év alatt 300 ezer dobozzal nőtt a kiváltott gyógyszerek mennyisége, és meghaladta a havi 800 ezer dobozt (1. ábra). 2012-ben érzékelhető volt egy kismértékủ csökkenés, majd 2015-ig szinte azonos mértékủ a dobozforgalom. Az egyes statinok forgalma közt igen jelentős különbség figyelhető meg. A százalékos arány az egyes szerek között pontosan jelzi a tendenciák változását (1. táblázat). Ezzel párhu-

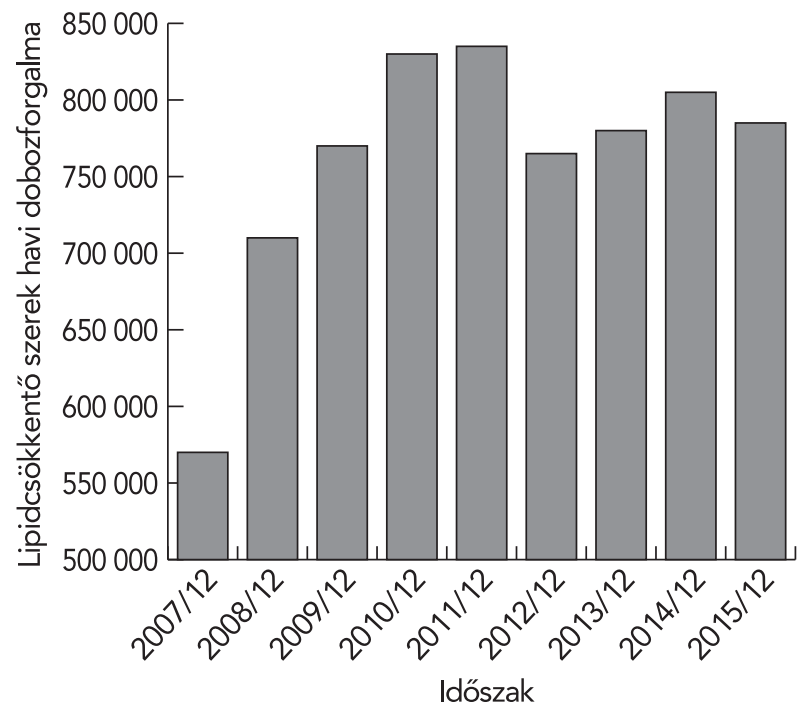

1. ÁBRA. Lipidcsökkentő szerek havi dobozforgalma 2007-2015 közti periódusban

zamosan a támogatásra fordított összeg is folyamatosan emelkedett, és ez havi szinten több mint 2,6 milliárd forinttal terhelte az OEP költségvetését. A támogatási kategóriák fixesítésének, és a generikumok árversenyének (vaklicit) köszönhetően ez 2015-re 1,2 milliárd forint értékre csökkent (2. ábra).

A kiváltott lipidszint-csökkentő gyógyszerek $87 \%$-a statin. 2007-ben a simvastatin volt a legnagyobb mértékben rendelt molekula. 2015-re az atorvastatin lett (40\%)

1. TÁBLÁZAT. Monoterápiában alkalmazott egyes lipidszintet csökkentők havi forgalma, részletezve 2007-2015 közötti időszakban, dobozszám és százalékos részesedés

\begin{tabular}{|c|c|c|c|c|c|c|c|c|c|c|}
\hline & & $2007 / 12$ & $2008 / 12$ & $2009 / 12$ & $2010 / 12$ & $2011 / 12$ & $2012 / 12$ & $2013 / 12$ & $2014 / 12$ & $2015 / 12$ \\
\hline Simvastatin & C10AA01 & 231633 & 223078 & 191771 & 163464 & 129579 & 101196 & 87536 & 79391 & 69835 \\
\hline Lovastatin & C10AA02 & 5601 & & & & & & & & \\
\hline Pravastatin & C10AA03 & 17694 & 347 & 328 & 277 & 1581 & 1214 & 967 & 985 & 939 \\
\hline Fluvastatin & C10AA04 & 41395 & 50498 & 48931 & 45351 & 35010 & 26515 & 23285 & 21463 & 18749 \\
\hline Atorvastatin & C10AA05 & 188842 & 305948 & 369431 & 381223 & 377782 & 315381 & 299568 & 301595 & 286851 \\
\hline Rosuvastatin & C10AA07 & 8177 & 21806 & 32510 & 102771 & 154864 & 191713 & 232915 & 268018 & 282667 \\
\hline Bezafibrat & C10AB02 & 1374 & 1404 & 1298 & 1187 & 1046 & 865 & 880 & 882 & 863 \\
\hline Gemfibrozil & C10AB04 & 6011 & 2421 & 2141 & 1904 & 1858 & 1225 & 1065 & 6 & 2 \\
\hline Fenofibrat & C10AB05 & 34719 & 44868 & 50023 & 55329 & 57937 & 54778 & 56951 & 60159 & 58770 \\
\hline Ciprofibrat & C10AB08 & 15423 & 15139 & 13220 & 11737 & 9328 & 7849 & 7386 & 7027 & 6435 \\
\hline Acipimox & C10AD06 & 538 & 653 & 643 & 584 & 601 & 595 & 529 & 353 & 286 \\
\hline Ezetimib & C10AX09 & 7286 & 9764 & 11581 & 12735 & 11496 & 14253 & 15174 & 21527 & 22812 \\
\hline Összes & & 558692 & 675926 & 721877 & 776562 & 781082 & 715584 & 726256 & 761928 & 748209 \\
\hline változás & & & $20,98 \%$ & $6,80 \%$ & $7,58 \%$ & $0,58 \%$ & $-8,39 \%$ & $-7,02 \%$ & $6,48 \%$ & $-1,80 \%$ \\
\hline Statinok & C10AA & 493341 & 601677 & 642971 & 693086 & 698816 & 636019 & 644271 & 671974 & 659041 \\
\hline Fibrátok & C10AB & 57527 & 63832 & 66682 & 70157 & 70169 & 54717 & 66282 & 68074 & 66070 \\
\hline \multicolumn{2}{|c|}{$\begin{array}{l}\text { Kifizetett tb. támogatás } \\
\text { (HUF) }\end{array}$} & 1926794753 & 2273958913 & 2308527549 & 2391865893 & 1918119952 & 1273519514 & 1041729756 & 1097838910 & 1104487884 \\
\hline \multicolumn{2}{|c|}{ változás (HUF) } & & 347164160 & 34568636 & 83338344 & -473745941 & -644600438 & -231789758 & 56109154 & 6648974 \\
\hline
\end{tabular}




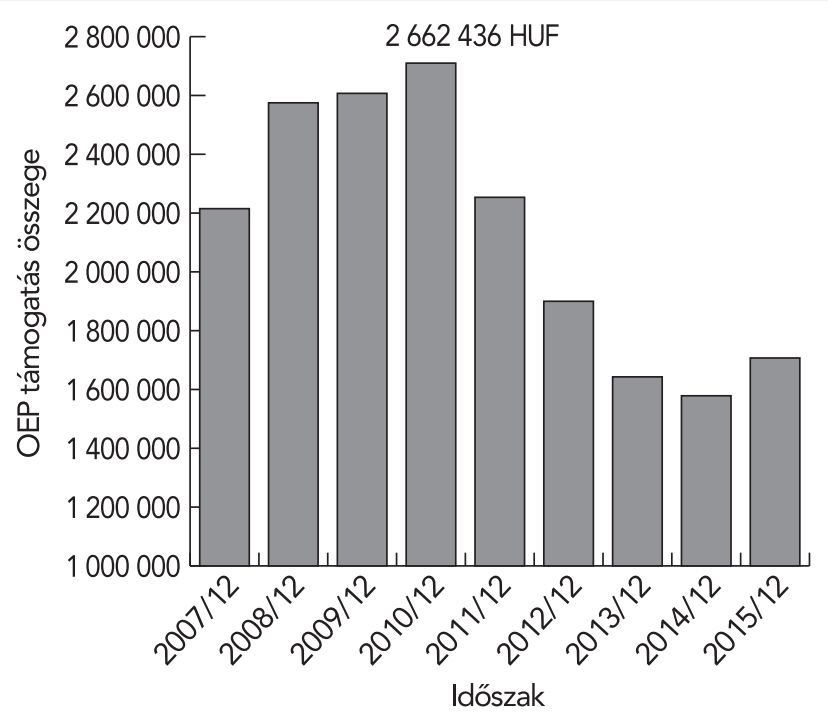

2. ÁBRA. A szérum lipidszintet csökkentő szerek támogatására havonta kifizetett összeg 2007-2015 között az OEP adatbázisa alapján

a legtöbb beteg által kiváltott molekula. Mellette a rosuvastatin (36\%) felhasználás jelentős (folyamatos növekedés mellett). A simvastatinnak a folyamatos csökkenés mellett még több mint 9\%-os a részesedése (3-4. ábra). A többi gyógyszer közül a fenofibrát (7\%), és az ezetimib (3\%) felhasználása érdemel említést. Az ezetimib felhasználás értékeléséhez hozzá kell tenni, hogy normatív támogatásban nem részesül (így jelentős anyagi terhet ró a betegre). Kiemelt támogatásban (Eü. 90\%) is rendelhetö, de ennek dokumentálása a felíró felelőssége (5. ábra). A statint tartalmazó fix kombinációkat két csoportra lehet bontani: statint és ezetimibet tartalmazó, valamint statint és valamilyen vérnyomáscsökkentő(ke)t tartalmazó készítményekre. Előbbiek hazai forgalma minimális a felírási korlátok miatt (nem támogatott), ezért

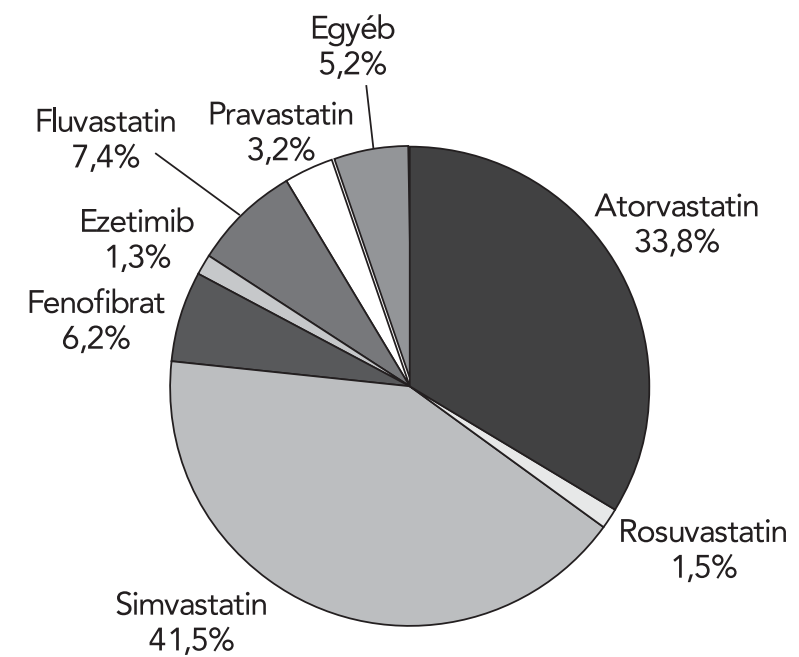

3. ÁBRA. Szérum lipidszintet csökkentő szerek forgalma 2007 decemberében szükség esetén statin mellé inkább szabad kombináció részeként kerül felírásra az ezetimib.

Az atorvastatint és amlodipint tartalmazó fix kombinációból 4 van forgalomban hazánkban, amelyek felhasználása csak igen lassú ütemben bővül. A 2016 októberétől elérhető atorvastatin/perindopril/amlodipin hármas fix kombináció új megoldást jelent a hipertóniás és hypercholesterinaemiás betegek kezelésében, amely talán egyben hatékony válasz lehet a statinok szedésével kapcsolatos adherencia-problémák okozta kihívásokra is (6-7. ábra).

PCSK9-gátló evolocumab várhatóan nem fog bekerülni a normatívan támogatott gyógyszerek közé. Az ilyen árú gyógyszerek a tételes elszámolású gyógyszerek között érhetők el a betegek számára.

\section{Megbeszélés}

Az orvostudományban ma széles körben elfogadott „evidenciákon alapuló gyógyítás” alapjául szolgáló, fent is említett multicentrikus vizsgálatok és az ezeken alapuló metaanalízisek úgynevezett originális (eredeti) készítményekkel történtek. Az originális készítmények hatóanyaga új fejlesztés eredménye, korábban nem létezett vagy nem használták a gyógyászatban. Az új gyógyszermolekulát hosszú évekig szabadalom védi, a szabadalommal bíró gyógyszercég az egyetlen, amely ezt a gyógyszert gyárthatja és forgalmazhatja. Ha a szabadalom lejár, a cég köteles nyilvánosságra hozni a molekulára vonatkozó főbb ismereteket, és az utángyártható lesz, ezek lesznek az úgynevezett generikus gyógyszerek.

A több évtizedes tudásunk és eredményes kezelésünk mellett a generikus lipidcsökkentő készítmények (statinok) majd mindenki számára elérhetők. A nagy nemzetközi vizsgálatokkal igazolt egyértelmüen kedvező hatása mellett újra és újra felvetődik a kérdés, hogy va-

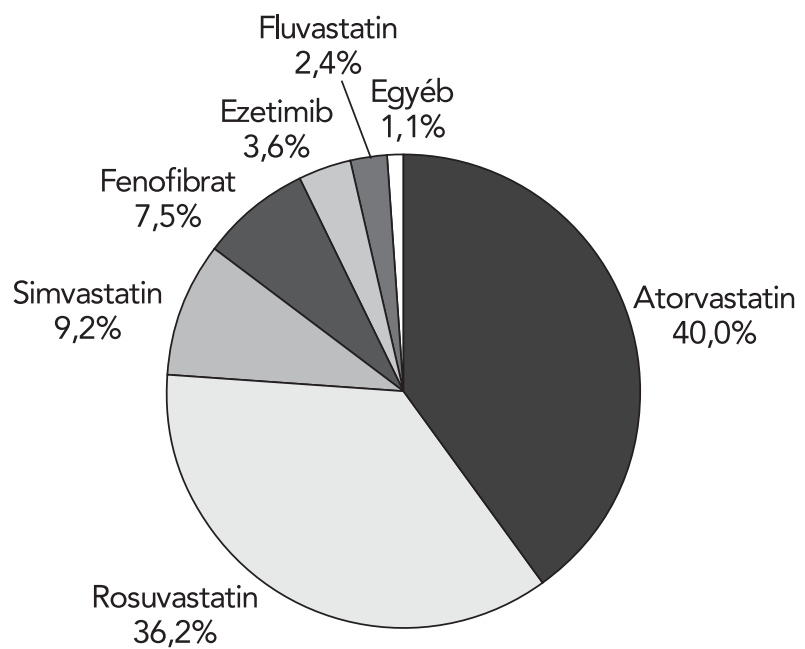

4. ÁBRA. Szérum lipidszintet csökkentő szerek forgalma 2015 decemberében 


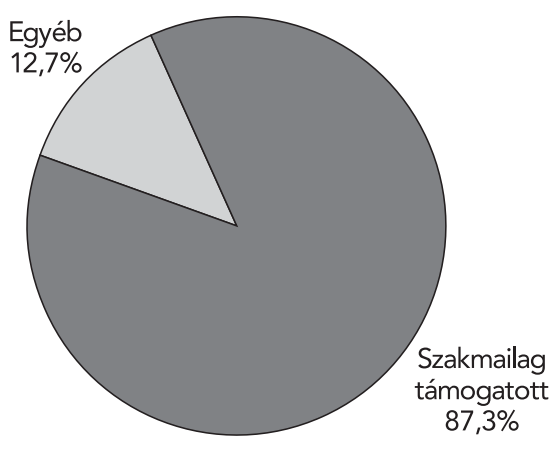

5. ÁBRA: Szérum lipidszintet csökkentő szakmailag támogatott és nem támogatott szerek százalékos aránya 2015 decemberében

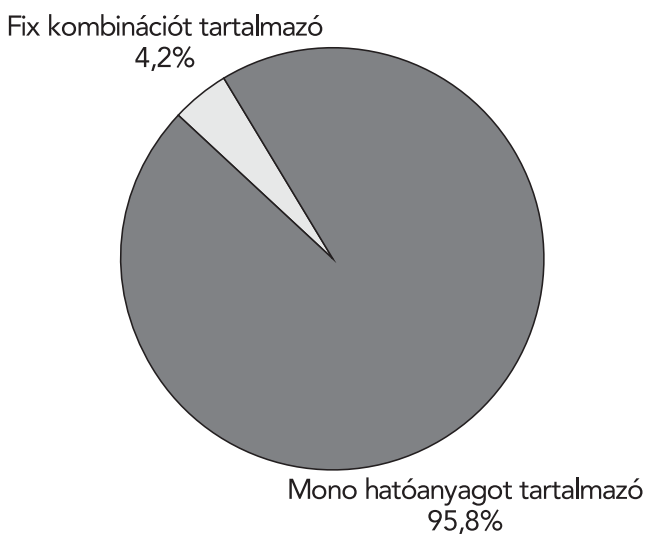

6. ÁBRA: Szérum lipidszintet csökkentő mono-, és kombinációban alkalmazott szerek forgalma 2015 decemberében

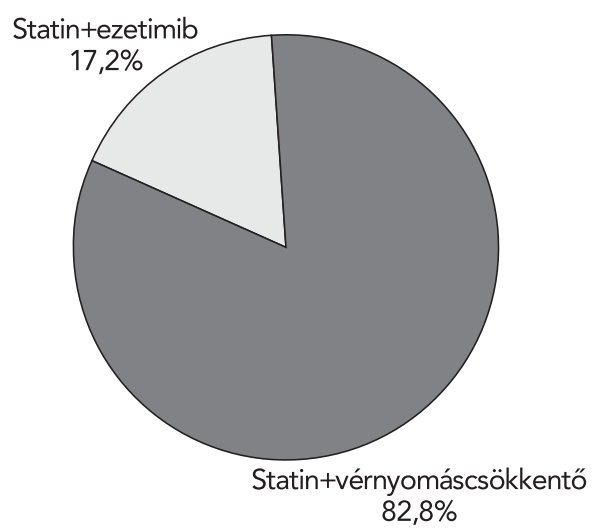

7. ÁBRA: Fix kombinációt tartalmazó szérum lipidszintet csökkentő szerek forgalmának megoszlása 2015 decemberében (doboz) jon a nyert kardiovaszkuláris haszon ismeretében miért ilyen nagyfokú a szer elhagyásának gyakorisága.

A 2016-ban kiadásra került a dyslipidaemia kezelésének európai irányelve, amely elsődleges célnak az LDL-koleszterinszint csökkentését nevezte meg (I/A). A statinkezelés során a legnagyobb dózist, vagy a legnagyobb tolerálhatósági dózisok alkalmazását javasolja (I/A). A statin+ezetimib, vagy egyéb szerek kombinációját megfontolásra javasolja (II/C) (16). Hazánkban a kombináció az ezetimib támogatásának hiánya, vagy talán a szakmai ismeretek és ajánlások miatt nem tudott elterjedni.

A statinok alkalmazásával szignifikánsan csökken a kardiovaszkuláris események száma és az összhalálozás. A statinokról elmondható, hogy az egyedüli gyógyszercsoport, amely a kardiovaszkuláris morbiditás és mortalitás legjelentősebb csökkenéséért felelős (17). $A z$ OEP-adatok értelmezése során látható, hogy előbb jönnek a szakmai irányelvek, az evidenciával bíró közlemények, majd a hazai szakvélemények, és ez lassan tükröződik a kialakult orvosi gyakorlatban is.

Irodalom

1. Szegedi J. A hipertónia epidemiológiája, rizikófaktorai. Hipertónia és nefrológia a háziorvosi gyakorlatban (szerk. Barna István). Springmed Kiadó; 2014. P. 3-23. 2. Heart Protection Study Collaborative Group. HPS of cholesterol lowering with simvastatin in 20536 hiah-risk individuals. Lancet 2004: 360: 7-22. Doi 10.1016/S0140-6736(02)09327-3

3. Pados Gy, Audikovszky M. Kezelési irányelvek és a simvastatin terápia. Háziorvosi Továbbképző Szemle 2004; 9: 579-584

4. Reiner Z, Catapano AL, De Backer G, et al. The Task Force for the management of dyslipidaemias of the European Society of Cardiology (ESC) and the European Atherosclerosis Society (EAS). ESC/EAS Guidelines for the management of dyslipidaemias. Eur Heart J 2011; 32: 1769-1818. Doi 10.1093/eurheartj/ehr158 5. Treatment of Hypertension in Patients With Coronary Artery Disease, A Scientific Statement From the American Heart Association, American College of Cardiologv. and American Society of Hvpertension, Circulation. 2015;131:e435-e470 DOI: $10.1161 /$ CIR. 0000000000000207 Circulation May 12, 2015.

6. Karädi 1. A koleszterinszint cẻlértekre csökkentésének lehetőségei statinokkal. LAM 2006; 16(2): 114-120

7. Bellosta S, Bernini F. Statins. Current Atheroscler Reports 2000; 2: 76-81. 8. Bangalore S, Breazna A, DeMicco DA, Wun CC, Messerli FH, on behalf of the TNT. Steering Committee and Investigators. Visit-to-visit low-density lipoprotein cholesterol variability and risk of cardiovascular outcomes. Insights from the TNT trial. J Am Coll Cardiol 2015; 65: 1539-1548. Doi 10.1016/j.jacc.2015.02.017

9. Fehér A, Pusch G, Koltai K, et al. Statin therapy in the primary and the secondary prevention of ischaemic cerebrovascular diseases. Int J Cardiol 2011: 148: 131-138. Doi 10.1016/j.ijcard.2010.08.012

10. Pados Gy, Audikovszky M, Simonyl G, Bedros R. Magyar Obezitológiai és Mozgásterápiás Társaság (MOMOT). A dyslipidaemiák és az elhízás gyógyszeres kezelése 2015.

11. Simonyi G, Kempler P. A statinok és a diabetes kockázat. Diabetologia Hungarica 2014; 22(2): 115-21.

12. Murlasits Zs, Radák Zs. The effects of statin medications on aerobic exercise capacity and training adaptation. Sports Medicine 2014 Jul 11. doi 10.1007/s40279-014-0224-4 Doi 10.1007/s40279-014-0224-4

13. Paragh Gy. A legujabb ajänlasokat meghatärozo lipidcsokkentő szerekkel végzett vizsgálatok VI. Magyar Konszenzus Konferencia, előadáskivonatok 2014. november 28

14. Gencer B, Montecucco F, Nanchen D, et al. Lipids Prognostic value of PCSK9 levels in patients with acute coronary syndromes. European Heart Journal 2016; 37: 546-553. doi 10.1093/eurheartj/ehv637 Doi 10.1093/eurheartj/ehv637

15. Crossey E, Amar MJA, Sampson M, et al. A cholesterol-owering VLP vaccine that targets PCSK9. Vaccine 2015; 33: 5747-5755. Doi 10.1093/eurheartj/ehv637

16. 2016. EAS Guidelines for the management of Dyslipidaemias. Eureopean Heart Journal 2016.08.27. doi 10.1093/eurheartj.ehw272 Doi 10.1093/eurheartj.ehw272

17. Braunwald E. The rise of cardiovascular medicine. EurHeart J 2012; 33: 838-846. doi $10.1093 /$ eurheartj/ehr452 